\title{
PARTISIPASI WANITA PEKERJA KEBERSIHAN KOTA BENGKULU
}

\author{
${ }^{1}$ Onsardi ${ }^{2}$ Asniwati \\ ${ }^{1,2}$ Program Studi Manajemen UM. Bengkulu \\ onsardi@umb.ac.id
}

\begin{abstract}
The formulation of the problem in this study is "What factors are related to the Participation of Women Cleaning Workers in Bengkulu City. The purpose of this study was to determine the factors associated with the Participation of Women Cleaning Workers in Bengkulu City. The population in this study 150 people were sampled as many as 30 people. This research uses accidental sampling technique. Data collection techniques by conducting direct interviews with someone or a group of people authorized to obtain information that supports this research. By using the tools in the form of an interview questionnaire. The data analysis technique used is descriptive and correlative techniques. The results of this study are the income of the head of the respondent's family as road cleanliness in the city of Bengkulu is 90\% (27 people) earning between Rp. $300,000 \mathrm{sd}$. 900,000. The number of dependents of family heads is $86.67 \%$ (26 people) with the number of dependents between 3 to 3 families. 5 people. The level of education of the head of the family mostly graduated from junior high school $46.66 \%$ (14 people), $40 \%$ (12 people) graduated from elementary school and 3 people graduated from high school 1 graduated from Diploma. The education level of the respondents was 22 elementary school graduates (73.33\%) 6 junior high school students (20\%) and 2 high school graduates (6.66\%). Family income (X1) has a significant relationship with the participation of working women. Family dependents (X2) have a significant relationship with the participation of working women. The level of education (X3) has a significant relationship with the participation of working women.
\end{abstract}

Keywords: Participation, Women, Workers

\section{PENDAHULUAN}

Aktifnya wanita dalam berbagai kegiatan ekonomi mempunyai maksud dan tujuan yang berbeda antara satu dengan lainnya, seperti untuk mengisi waktu luang atau membantu mencukupi kebutuhan rumah tangga.

Turut sertanya kaum wanita dalam perekonomian tidaklah hal yang baru, karena kegiatan ekonomi yang tertua adalah di bidang pertanian, kemudian kegiatan ekonomi semakin berhubungan dengan bidang-bidang lain seperti industri, perdagangan, jasa dan lainnya.Perkembangan tersebut menyebabkan partisipasi wanita dalam angkatan kerja juga meningkat ke berbagai bidang.Partisipasi wanita bekerja dalam kegiatan ekonomi 
dipengaruhi oleh beberapa faktor, antara lain : pendapatan kepala keluarga, jumlah anggota keluarga dan tingkat pendidikan.

Alasan ditetapkannya bidang pertanian sebagai prioritas utama dalam pembangunan, karena hampir $80 \%$ dari angkatan kerja di pedesaan bekerja di bidang pertanian.Dengan tujuan untuk mendorong perluasan serta pemerataan kesempatan berusaha dan lapangan kerja di pedesaan.

Tingkat pendapatan kepala keluarga mempunyai pengaruh terhadap partisipasi wanita dalam kegiatan ekonomi.Keadaan kaum wanita bekerja di luar rumah merupakan kenyataan yang tidak bisa dielakkan.Oleh karena itu, masyarakat kita tidak bisa menolak gejala tersebut.Pada umumnya faktor-faktor yang mendorong partisipasi wanita bekerja karena penghasilan orang tuanya atau suaminya tidak mencukupi.

Jumlah anggota keluarga juga mempunyai pengaruh terhadap partisipasi wanita bekerja, semakin banyak jumlah anggota keluarga maka partisipasi wanita untuk bekerja semakin besar.Hal ini disebabkan karena beban tanggungan oleh kepala keluarga akanmenjadi besar pula, maka untuk meringankan beban kepala keluarga wanita biasanya ikut bekerja.

Selain itu tingkat pendidikan juga mempengaruhi partisipasi wanita bekerja, semakin tinggi tingkat pendidikan seseorang maka semakin tinggi keinginannya untuk bekerja.Wanita yang berpendidikan tinggi tidak mengurus rumah tangga tetapi banyak bekerja memanfaatkan waktu luangnya bersamaan dengan pengetahuan yang dimilikinya.

Berdasarkan uraian di atas, maka peneliti tertarik untuk melakukan penelitian dengan permasalahan "Faktor-faktor apa sajakah yang mempengaruhi Partisipasi Wanita Pekerja Kebersihan Kota Bengkulu".

\section{KAJIAN TEORI}

\section{Partisipasi Wanita Bekerja}

Partisipasi wanita bekerja adalah ikut sertanya kaum wanita untuk bekerja di luar rumah tangga sebagai tenaga kerja dalam profesi atau wiraswasta dan sebagainya, untuk mengusahakan atau menambah penghasilan bagi keluarga dan bagi wanita terpelajar untuk menjalankan karirnya. Menurut Irianto $(2008 ; 442)$ adanya perubahan lapangan pekerjaan di daerah perkotaan, maka pola partisipasi wanita bekerja di daerah perkotaanpun mengalami perubahan. Tingkat partisipasi wanita bekerja di Indonesia mengalami peningkatan.Gambaran partisipasi wanita bekerja di daerah perkotaan dan pedesaan memiliki karakteristik yang berbeda satu dengan yang lainnya.Dinilai bahwa jumlah pekerja wanita dari keseluruhan pekerja di daerah perkotaan meningkat.Peningkatan jumlah wanita pekerja ini erat kaitannya dengan naik meningkatnya partisipasi kaum wanita dalam sektor formal.Berdasarkan pembagian sektor kerja ke dalam formal dan nonformal tersebut, maka data memperlihatkan bahwa jumlah wanita (dibandingkan dengan pria) yang masuk sektor formal meningkat dari $36,8 \%$ pada tahun 1980 menjadi $44,2 \%$ pada tahun 1990 , menjadi $46,9 \%$ pada tahun 1995, dan pada tahun 2000 menjadi 51,5\%. Data pada tahun 2004 menunjukkan tingkat partisipasi wanita bekerja adalah 49,2\%. Walaupun sumber data yang digunakan berbeda dengan sumber data yang lainnya, tetapi paling tidak angka-angka disajikan menunjukkan indikasi eksistensi wanita yang signifikan di dunia kerja.Ini berarti tingkat partisipasi wanita bekerja di sektor formal meningkat cukup tajam. 
Kondisi tingkat partisipasi wanita bekerja ini dipengaruhi oleh banyak faktor, antara lain yaitu karena pendidikan meningkat, permintaan tenaga kerja wanita meningkat. Selain itu, dipengaruhi juga oleh tersedianya barang-barang subtitusi, urbanisasi/migrasi orang, trend demografi(jumlah anak berkurang), pendapatan suami dan pergeseran struktur budaya.

Menurut Prijono (2002;40-42) perbedaan antara sektor formal dan non formal dilakukan mengikuti sistem pencatatan BPS dimana mereka yang dikategorikan bekerja di sektor formal adalah bekerja sebagai buruh tetap, dan buruh/karyawan, berarti bahwa mereka menerima bayaran. Sebaliknya sektor nonformal meliputi : (1) berusaha sendiri tanpa bantuan orang lain, (2) berusaha dengan bantuan anggota rumah tangga atau buruh tidak tetap, (3) pekerja keluarga yang tidak dibayar.

Perbedaan karakteristik partisipasi angkatan kerja wanita di daerah perkotaan dan pedesaan tersebut membawa keadaan terlihat pada perbedaan sistem nilai dan pandangan hidup antara kaum wanita pada kedua sisi tersebut.Meningkatnya jumlah wanita di daerah perkotaan yang bekerja di sektor formal, memiliki keadaan terlihat pada meningkatnya kemandirian wanita dalam mengambil keputusan baik di dalam rumah tangga atau keluarga maupun di luar keluarga.Keputusan seperti menentukan, jumlah anak, sekarang tidak lagi menjadi keputusan suami namun juga keputusan istri, karena istri juga memiliki keterbatasan terhadap waktu sebagai dampak dari bekerja di luar rumah.

Menurut Mas'ud (2000;137), "menyatakan bahwa salah satu wujud partisipasi adalah pemberian sumbang saran dari seseorang yang dapat diterima, menyalurkan kemampuan dan minat, menyediakan tenaga dan waktu, saling memberikan informasi, bekerja sama dan saling membantu oleh kelompok kerja.

Menurut Mas'ud (2000;137) unsur-unsur penting dalam kehidupan kerja antara lain :

1. Memajukan pertumbuhan dan martabat manusia

2. Bekerja sama dan saling membantu

3. Menentukan perubahan-perubahan secara partisipasif

4. Menganggap tujuan-tujuan karyawan dan organisasi dapat berjalan bersamasama.

Menurut Hasibuan $(2002 ; 225)$ menyatakan bahwa pelaksanaan program Total Quality Control (TQC) terdapat dua hal yang harus diperhatikan agar Total Quality Control (TQC) dapat sukses yaitu :

1. Dari sisi karyawan

- Menciptakan suasana yang cocok.

- Saling memberi informasi dan komunikasi.

- Dijadikan program sukarela.

- Memberikan pengaruh dan latihan.

- Bersikap terbuka dan positif.

- Menyediakan waktu, sarana, fasilitas dan dana.

2. Dari sisi manajer

- Mengajukan dan menjelaskan program Total Quality Control (TQC) puncak pimpinan.

- Menjelaskan tujuan dan hasil yang akan dicapai.

- Mendapat dukungan dari puncak pimpinan.

Di sini dapat disimpulkan bahwa partisipasi wanita bekerja merupakan ikut sertanya kaum wanita untuk kerja di luar rumah tangga sebagai tenaga kerja dalam profesi atau wiraswasta dan sebagainya untuk mengusahakan atau menambah 
penghasilan bagi keluarga dan bagi wanita terpelajar untuk menjalankan karirnya.Selain dipengaruhi oleh tersedianya barang-barang subtitusi, urbanisasi/migrasi orang, trend demokrasi (bila anak berkurang), pendapatan suami dan pergeseran struktur budaya.Kondisi tingkat partisipasi wanita pekerja juga dipengaruhi oleh faktor-faktor yaitu karena pendidikan meningkat, permintaan tenaga kerja wanita meningkat.Meningkatnya jumlah wanita yang bekerja di sektor formal memberi pengaruh terhadap meningkatnya kemandirian wanita dalam mengambil keputusan. Salah satu wujud partisipasi adalah pemberian sumbang saran dari seseorang yang dapat diterima, menyalurkan kemampuan dan minat, menyediakan tenaga dan waktu, saling memberikan informasi, bekerja sama dan saling membantu.

\section{Kesempatan Kerja Bagi Wanita}

Kesempatan kerja menggambarkan banyaknya penduduk yang bekerja atau terserap dalam pasar kerja.Menurut Irianto $(2008 ; 452-453)$ tingkat kesempatan kerja merupakan perbandingan antara jumlah penduduk yang bekerja dengan jumlah angkatan kerja. Dalam meningkatkan partisipasi wanita di pasar kerja ada 4 kategori peraturan perundang-undangan yaitu : (1) peraturan yang bertujuan meningkatkan kesetaraan kesempatan untuk masuk ke pasar kerja; (2) peraturan larangan diskriminasi; (3) peraturan perundangan untuk memberikan keselamatan dan kesehatan dalam kaitannya dengan kondisi lingkungan kerja; dan (4) peraturan perundangan untuk meningkatkan penyediaan faktor-faktor produksi bagi wanita, misalnya kredit, informasi dan teknologi, yang (misalnya) dapat memberi peluang bagi wanita untuk berusaha sendiri. Beberapa peraturan perundang-undangan dan ketentuan yang mengatur mengenai kesetaraan dalam kesempatan pasar kerja diuraikan berikut ini.

Peraturan perundang-undangan yang bertujuan meningkatkan kesetaraan kesempatan tersebut adalah :

1. Pasal 27 ayat 2 UUD 1945 mengamanatkan bahwa setiap warga negara laki-laki dan wanita memiliki hak yang sama untuk mendapatkan penghidupan yang layak bagi kemanusiaan.

2. Undang-Undang No. 13 Tahun 2003 tentang ketenagakerjaan, paragraf 3 tentang wanita, pasal 76 menyatakan perlindungan bagi tenaga kerja wanita.

3. Keputusan Menteri Tenaga Kerja dan Transmigrasi No. Kep-223/MEN/2003 tentang kewajiban pengusaha yang mempekerjakan tenaga kerja wanita antara pukul 23.00 sampai pukul 07.00.

4. Undang-Undang No. 52 Tahun 1952 diterapkan ke dalam Peraturan Pemerintah No. 24 Tahun 1976 menyatakan bahwa setiap pegawai wanita yang berhak atas cuti tersebut sampai dengan kelahiran anak ketiga. Sedangkan bagi anak keempat dan seterusnya mereka berhak atas cuti melahirkan tanpa mendapat imbalan jasa.

5. Surat Edaran 4 Tahun 1988 tentang tata cara mempekerjakan pekerja wanita pada malam.

6. Surat Edaran Tahun 1996 tentang larangan diskriminasi (dalam penyusunan peraturan perusahaan dan kesepakatan kerja bersama).

7. Surat Kesepakatan Bersama Menteri Tenaga Kerja dan Menteri Kesehatan No. 22 Tahun 1996 dan No. 202 Tahun 1996 tertentu penanggulangan kekurangan gizi bagi tenaga kerja wanita.

Jadi jelas dengan adanya peraturan perundang-undangan yaitu pasal 27 Undang-Undang Dasar 1945 mengamanatkan bahwa setiap warga negara laki-laki 
dan wanita memiliki hak yang sama untuk mendapatkan penghidupan yang layak bagi kemanusiaan dan undang-undang No. 13 tahun 2003 tentang ketenagakerjaan paragraf 3 tentang wanita, pasal 76 menyatakan perlindungan bagi tenaga kerja wanita.Maka dengan adanya undang-undang tersebut tujuan untuk meningkatkan kesetaraan kesempatan bagi wanita yang ingin berpartisipasi di pasar kerja dapat tercapai.

\section{Pendapatan}

Pendapatan dalam suatu rumah tangga merupakan faktor yang sangat penting untuk memenuhi kebutuhan hidup sehari-hari.Pendapatan kepala keluarga adalah pendapatan keluarga baik sebagai pendapatan utama maupun sebagai pendapatan tambahan selama satu bulan dan dinyatakan dengan rupiah.

Menurut Samuelson $(2002 ; 258)$, pendapatan adalah jumlah seluruh uang yang diterima oleh seseorang atau rumah tangga selama jangka waktu tertentu (biasanya satu tahun).

Menurut Sadono Sukirno $(2001 ; 62-65)$ pendapatan adalah dibedakan menjadi dua bagian, yaitu :

1. Pendapatan pribadi adalah semua jenis pendapatan termasuk pendapatan tanpa memberikan suatu kegiatan apapun yang diterima oleh penduduk suatu negara.

2. Pendapatan disposable adalah pendapatan pribadi yang dikurangi pajak yang harus dibayar oleh penerima pendapatan. Nilai yang tersisa itulah yang dinamakan pendapatan disposibel.

Menurut Muzakar $(2001 ; 7)$ sumber pendapatan yang diterima oleh suatu rumah tangga berasal dari :

1. Sektor formal yaitu rincian oleh pemerintah dan perusahaan-perusahaan besar, resmi terdaftar pada pemerintah.

2. Sektor informal yaitu dirincikan oleh sektor ekonomi marginal dengan kondisi nyata kegiatan sejumlah tenaga kerja yang umumnya kurang berpendidikan dan hanya mempunyai keterampilan.

3. Sektor subsistem yaitu sektor ekonomi dimana apa yang dikonsumsikan dan diproduksi sendiri.

Jadi jelas bahwa yang dimaksud dengan pendapatan kepala keluarga adalah pendapatan keluarga baik sebagai pendapatan utama maupun sebagai pendapatan tambahan yang diterima oleh suatu rumah tangga yang berasal dari sektor formal, sektor informal maupun sektor subsistem.

Menurut BPS (2003) dijelaskan bahwa pendapatan rumah tangga adalah keseluruhan penerimaan dan keuntungan yang didapat oleh setiap rumah tangga atas balas jasa dari faktor-faktor produksi.Pendapatan dibagi menjadi :

1. Pendapatan yang didistribusikan terdiri dari penghasilan sebagai gaji dan upah serta keuntungan dari usaha sendiri.

2. Transfer yang bersifat redistribusi terdiri dari transfer pendapatan yang tidak bersifat mengikat dan biasanya merupakan balas dan jasa atau harta milik.

Menurut Tohar dalam Eko(2003;5) pendapatan dibedakan menjadi :

1. Pendapatan Asli yaitu pendapatan yang diterima setiap orang yang langsung ikut serta dalam produksi barang.

2. Pendapatan turunan (sekunder) yaitu pendapatan dari golongan penduduk lainnya yang tidak langsung ikut serta dalam produksi barang seperti dokter, ahli hukum dan pegawai negeri. 
Yudhohusodo dalam Harjanti $(2002 ; 6)$ tingkat pendapatan seseorang dapat digolongkan dalam 4 golongan yaitu :

1. Golongan yang berpenghasilan rendah, yaitu pendapatan rata-rata dari Rp. 150.000 per bulan

2. Golongan yang berpenghasilan sedang, yaitu pendapatan rata-rata dari Rp. 450.000 per bulan

3. Golongan yang berpenghasilan menengah, yaitu pendapatan rata-rata dari Rp. 450.000-Rp. 900.000 per bulan

4. Golongan yang berpenghasilan tinggi, yaitu pendapatan rata-rata lebih dari Rp. 900.000 per bulan

Sesuai dengan keputusan Gubernur Bengkulu bahwa Upah Minimum Provinsi (UMP) Bengkulu tahun 2010 sebesar Rp. 785.000,-.

Pendapatan menurut Simanora dalam Astuti (2004;28-29) adalah kenaikan aktiva perusahaan atau penurunan kewajiban (kombinasi antara keduanya) selama periode tertentu yang berasal dari pengiriman barang-barang, penyerahan jasa, atau kegiatan lainnya yang merupakan kegiatan sentral perusahaan.

Dapat diartikan pendapatan seseorang atau suatu rumah tangga itu berasal dari berbagai usaha atau kegiatan ekonomi yang mendatangkan hasil dengan menunjukkan tinggi atau rendahnya pendapatan.Pendapatan merupakan jumlah keseluruhan uang yang diterima seseorang atau rumah tangga baik yang dikurangi pajak ataupun tidak.

\section{Jumlah Anggota Keluarga}

Jumlah anggota keluarga adalah jumlah anggota rumah tangga yang masih ditanggung oleh kepala keluarga, yang secara ekonomis tidak produktif. Menurut Daan Dimara $(2000 ; 10)$ jumlah anggota keluarga adalah semua orang yang tinggal dalam satu rumah dan bersama-sama menyelesaikan masalah keuangan, selain itu ada kecenderungan bahwa banyaknya jumlah anggota keluarga menjadi semakin besar pula pengeluaran. Jumlah anggota keluarga akan mempengaruhi besar kecilnya pengeluaran. Semakin banyak anggota keluarga, maka semakin meningkat jumlah pengeluaran.

Lain halnya menurut Kotler $(2005 ; 183)$ yang membagi keluarga menjadi :

1. Keluarga inti menunjukkan ruang lingkup keluarga yang meliputi ayah, ibu dan anak-anak yang hidup dalam satu rumah tangga.

2. Keluarga besar adalah keluarga inti ditambah dengan orang-orang yang mempunyai ikatan saudara dengan keluarga tersebut.

Jumlah anggota keluarga adalah semua orang yang bertempat tinggal dalam satu rumah yang secara bersama-sama mengambil keputusan dalam hal-hal yang menyangkut keluarga, mereka selalu sejalan atau bersikap sesuai bila menghadapi pilihan-pilihan yang bercorak ekonomi (Azehari, 2001;26).

Jumlah anggota keluarga yang besar dengan pendapatan yang rendah dapat meningkatkan kemauan anggota keluarga untuk mencari tambahan pendapatan.Sebaliknya seperti yang diungkapkan oleh Simanjuntak (2001) yang menyatakan bahwa keluarga yang berpenghasilan besar cenderung memperkecil jumlah anggota keluarga untuk bekerja.Tuntutan kebutuhan anggota keluarga yang semakin tinggi dapat menjadi pemicu bagi ibu rumah tangga untuk harus ikut terlibat dalam upaya mencari nafkah (Pratiwi dan Adiono,2003).

Jadi jumlah anggota keluarga dapat disimpulkan banyaknya anggota keluarga dalam satu rumah tangga baik anggota keluarga inti ataupun anggota keluarga kerabat yang masuk dalam ruang lingkup keluarga inti dan pemenuhan kebutuhan hidupnya menjadi 
tanggung jawab kepala keluarga itu. Dengan bertambahnya jumlah anggota keluarga berarti akan memperbesar konsumsi atau pengeluaran seperti pangan, perumahan, pakaian, serta meningkatkan kebutuhan-kebutuhan hidup yang lainnya. Oleh karena itu pendapatan rumah tangga harus mampu mengimbangi jumlah anggota keluarga.

\section{Tingkat Pendidikan}

Tingkat pendidikan seseorang merupakan penguasaan cakrawala cara berpikir dan bertindak rasional. Nanang dalam Aprizal (2002) menyatakan bahwa pendidikan adalah suatu sistem pengembangan kecerdasan, kemampuan dan keteraturan dari anak didik sebagai manusia, sehingga pendidikan dapat membuat pikiran dan dapat menjalankan pikiran seseorang untuk dapat berpikir secara objektif.

Seseorang yang memiliki tingkat pendidikan yang tinggi akan dapat memilih pekerjaan yang baik dibandingkan seseorang yang tingkat pendidikannya rendah. Tingginya pendidikan seseorang mampu memberikan pemahaman bahwa nilai waktunya menjadi mahal sehingga cenderung menggantikan waktu luangnya untuk bekerja.Pengaruh ini harus nyata terlihat di kalangan wanita berpendidikan tinggi, mereka umumnya tidak tinggal diam di rumah untuk mengurus rumah tangga, akan tetapi mereka cenderung memilih masuk ke pasar kerja.Pendidikan menurut Simanjuntak (2001) adalah pengetahuan yang diperoleh seseorang dengan mengikuti sekolah (diatur menurut tingkat dan syarat yang selaras) dan pendidikan informal yang diperoleh dengan mengikuti kursus/latihan.

Menurut Idris $(2001 ; 58)$ mengklasifikasikan pendidikan dalam tiga bentuk, yaitu :

1. Pendidikan informal, yakni proses pendidikan yang diperoleh seseorang dari pengalaman sehari-hari dengan sadar atau tidak sadar yang pada umumnya sistematis sejak orang lahir sampai mati.

2. Pendidikan formal, yaitu pendidikan di sekolah yang teratur, sistematis, mempunyai jenjang dan dibagi dalam waktu-waktu tertentu, yang berlangsung dari tingkat taman kanak-kanak sampai ke tingkat perguruan tinggi.

3. Pendidikan non formal, adalah bentuk pendidikan yang diselenggarakan dengan sengaja, tertib, terarah dan berencana di luar kegiatan sekolah.

Menurut Philip dan Harahap (2002), pendidikan formal adalah pendidikan di sekolah yang diatur secara sistematis, mempunyai jenjang dan dibagi dalam waktu tertentu, serta berlangsung dari taman kanak-kanak sampai perguruan tinggi.

Di negara-negara industri yang sudah maju, tingkat pendidikan formal para warga masyarakat tinggi.Tinggi tingkat pendidikan formal tersebut antara lain berakibat pada peningkatan harapan dalam hal karier dan perolehan pekerjaan serta penghasilan. Akan tetapi di sisi lain, lapangan kerja yang tersedia tidak selalu sesuai dengan tingkat dan jenis pengetahuan serta keterampilan yang dimiliki oleh para pencari kerja tersebut.

Menurut Sondang $(2004 ; 7)$ terdapat dua konsekuensi yang harus dihadapi oleh organisasi pengguna tenaga kerja, yaitu :

1. Menyelenggarakan pelatihan secara intensif dan terprogram agar para pegawai memiliki pengetahuan dan keterampilan yang diperlukan.

2. Menawarkan pekerjaan yang sebenarnya memerlukan pengetahuan dan keterampilan yang lebih rendah dari yang dimiliki oleh para pekerja berkat pendidikan formal yang pernah ditempuhnya yang apabila diterima oleh pekerja yang bersangkutan berarti tingkat imbalan yang diperolehpun lebih rendah dari apa yang semula diharapkannya. 
Jadi jelas bahwa dengan pendidikan yang dimiliki berarti ibu rumah tangga sudah memiliki pengetahuan dan keahlian serta hal tersebut akan menambah kemampuan bersaing yang lebih baik sehingga mendorong mereka untuk memilih bekerja di luar rumah tangga, memanfaatkan potensi yang ada. Dengan semakin tingginya tingkat pendidikan yang dimiliki oleh ibu rumah tangga, maka diduga akan semakin mampu meningkatkan aspirasi untuk memanfaatkan peluang dan kesempatan ekonomi yang lebih baik.

\section{METODE PENELITIAN}

Populasi dalam penelitian ini 150 orang diambil sampel sebanyak 30 orang. Penelitian ini menggunakan teknik accidental sampling. Teknik pengumpulan data dengan cara mengadakan wawancara langsung dengan seseorang atau sekelompok orang yang berwenang untuk memperoleh informasi yang mendukung penelitian ini. Dengan menggunakan alat bantu berupa kuesioner wawancara. Teknik analisis data yang digunakan adalah teknik deskriftif dan korelatif.

\section{HASIL DAN PEMBAHASAN}

\section{Kebersihan Kota Bengkulu}

Cara terbaik dalam mengatasi masalah sampah dengan menciptakan system edukasi yang tepat bagi masyarakat, kata Kabid Kebersihan dan Pengawasan Lingkungan, Dinas Kebersihan Kota Bengkulu."Selama ini pemerintah lalai membina masyarakat untuk menjaga kebersihan di lingkungannya, padahal masyarakat tidak akan tertib jika tidak dipaksa".Seharusnya pemerintah terus menerus menanamkan pola piker pada masyarakat sehingga timbul kesadaran bahwa mengurangi sampah jauh lebih baik dan murah daripada memusnakan sampah. Penanaman pola pikir itu merupakan satu pembelajaran atau edukasi yang sangat baik untuk menanggulangi masalah sampah yang pada tahun-tahun mendatang akan semakin rumit. Ada banyak cara mengurangi sampah, diantaranya dengan makan secukupnya, sehingga tidak ada makanan sisa, menanamkan kebiasaan untuk tidak boros dalam penggunaan barang keseharian, kemudian memisahkan sampah kering dan sampah basah serta bagaimana mengelola sampah. Pengelolaan sampah adalah dilakukan dengan pendekatan daur ulang dan guna ulang diterapkan khususnya pada sampah non organik seperti kertas, plastik, aluminium, gelas dan logam."Sementara untuk sampah organik diolah dengan maksimal, salah satunya dengan pengkomposan".Khusus untuk kota Bengkulu, permasalahan sampahnya cukup kompleks dan rumit. Rumitnya permasalahan sampah mulai dari volume yang cukup besar yaitu mencapai 810 meter kubik dan hanya terangkat sekitar 105 persen, hal tersebut dikarenakan kurangnya petugas kebersihan. Selain itu, kita juga masih dihadapkan minimnya anggaran.

Dapat disimpulkan untuk mengatasi permasalahan sampah, pemerintah harus terusmenerus menanamkan pola pikir pada masyarakat sehingga timbul kesadaran untuk mengurangi sampah.Selain itu pemerintah juga harus menambah petugas kebersihan serta perlengkapannya dan meningkatkan anggaran. 


\section{Hasil Penelitian}

\section{Umur}

Berdasarkan penelitian terhadap 30 responden, dapat digambarkan umur responden secara keseluruhan, tingkat umur responden dapat dilihat pada tabel 4.1.

Tabel 4.1 Responden Menurut Umur

\begin{tabular}{|l|l|r|r|}
\hline No. & \multicolumn{1}{|c|}{ Umur (Tahun) } & \multicolumn{1}{|c|}{ Jumlah Responden } & \multicolumn{1}{|c|}{ Persentase (\%) } \\
\hline 1. & $28-35$ & 3 & 10 \\
\hline 2. & $36-43$ & 12 & 40 \\
\hline 3. & $44-51$ & 10 & 33,33 \\
\hline 4. & $52-59$ & 5 & 16,66 \\
\hline \multicolumn{2}{|l|}{ Jumlah } & 30 & 100 \\
\hline
\end{tabular}

Sumber data : Hasil Penelitian, Mei 2010

Dari tabel 4.1 kelompok umur 28 sampai dengan 35 tahun sebanyak 3 responden, kelompok umur 36 sampai dengan 43 tahun sebanyak 12 responden, kelompok umur 44 sampai dengan 51 tahun yaitu sebanyak 10 responden, sedangkan untuk kelompok umur 52 sampai 59 tahun sebanyak 5 responden. Dari tabel di atas dapat dilihat bahwa persentase tertinggi $40 \%$ berada pada kelompok umur 36 sampai dengan 43 tahun.Tingkat umur responden antara 36 sampai dengan 43 tahun berada pada masa-masa produktif atau masih muda, sehingga masih banyak kemampuan dalam bekerja.Sedangkan untuk persentase terendah $10 \%$ berada pada kelompok umur 28 sampai dengan 35 tahun.Biasanya pada kelompok umur tersebut anak-anak mereka masih kecil sehingga waktu mereka lebih banyak untuk mengurus anak-anak daripada untuk bekerja.

\section{Tingkat Pendidikan}

Dari hasil penelitian diperoleh data mengenai pendidikan responden, seperti tampil pada tabel 4.2

Tabel 4.2 Tingkat Pendidikan

\begin{tabular}{|l|l|r|r|}
\hline No. & \multicolumn{1}{|c|}{ Pendidikan } & Jumlah Responden & Persentase (\%) \\
\hline 1. & SD & 22 & 73,33 \\
\hline 2. & SLTP & 6 & 20 \\
\hline 3. & SLTA & 2 & 6,66 \\
\hline \multicolumn{2}{|l|}{ Jumlah }
\end{tabular}

Sumber data : Hasil Penelitian, Mei 2010

Tabel 4.2 menunjukkan bahwa mayoritas pendidikan responden adalah SD sebanyak 22 responden dengan persentase sebesar 73,33\%. Persentase yang terendah $6,66 \%$ berada pada responden yang tamat SLTA sebanyak 2 responden. Bila dilihat dari hasil penelitian ini, maka tingkat pendidikan responden kurang baik atau belum melebihi standar program pendidikan pemerintah yaitu wajib belajar 9 tahun (SD sampai SLTP). Tingkat pendidikan yang rendah ini ternyata mendorong mereka untuk ikut berpartisipasi bekerja sebagai pekerja kebersihan kota Bengkulu. 


\section{Pekerjaan Kepala Keluarga}

Dari hasil menunjukkan bahwa 2 kepala keluarga responden bekerja sebagai PNS, 1 kepala keluarga responden bekerja di sektor swasta, kepala keluarga responden bekerja sebagai buruh atau tukang sebanyak 14 responden, serta 1 kepala keluarga responden mempunyai pekerjaan sebagai pedagang, lainnya bekerja sebagai petugas kebersihan 4 responden tukang ojek 3 responden, nelayan 2 responden, bekerja di bengkel 1 responden dan 2 responden bekerja sebagai supir.

Tabel 4.3 Pekerjaan Kepala Keluarga

\begin{tabular}{|l|l|r|r|}
\hline No. & \multicolumn{1}{|c|}{ Pekerjaan } & $\begin{array}{c}\text { Jumlah } \\
\text { Responden }\end{array}$ & Persentase (\%) \\
\hline 1. & PNS & 2 & 6,66 \\
\hline 2. & Swasta & 1 & 3,33 \\
\hline 3. & Buruh atau tukang & 14 & 46,66 \\
\hline 4. & $\begin{array}{l}\text { Lainnya (P. kebersihan, pedangan, ojek, } \\
\text { nelayan, sopir, bengkel) }\end{array}$ & 13 & 43,33 \\
\hline & Jumlah & 30 & 100 \\
\hline
\end{tabular}

Sumber data: Hasil Penelitian, Mei 2010

Dari tabel 4.3 dapat dilihat bahwa mayoritas pekerjaan kepala keluarga reponden adalah buruh atau tukang dengan persentase terbesar yaitu sebesar 46,66\%. Banyaknya kepala keluarga yang bekerja sebagai buruh atau tukang karena sulitnya mencari pekerjaan yang layak, hal tersebut disebabkan oleh tingkat pendidikan kepala keluarga yang rendah sehingga tidak dapat bersaing dalam memperoleh pekerjaan yang layak.

\section{Pendapatan Kepala Keluarga}

Dari hasil penelitian pendapatan kepala keluarga dari 30 responden dapat dilihat pada tabel 4.4

Tabel 4.4 Pendapatan Kepala Keluarga

\begin{tabular}{|l|l|r|r|}
\hline No. & \multicolumn{1}{|c|}{ Pedapatan (Rp) } & Jumlah Responden & Persentase (\%) \\
\hline 1. & $300.000-599.999$ & 21 & 70 \\
\hline 2. & $600.000-899.999$ & 6 & 20 \\
\hline 3. & $900.000-1.199 .999$ & 2 & 6,66 \\
\hline 4. & $1.200 .000-3.000 .000$ & 1 & 3,33 \\
\hline \multicolumn{2}{|l|}{ Jumlah } & 30 & 100 \\
\hline
\end{tabular}

Sumber data : Hasil Penelitian, Mei 2010

Dari tabel 4.4 dapat dilihat bahwa pendapatan kepala keluarga antara Rp 300.000 sampai dengan Rp 599.999 sebanyak 21 responden dengan persentase terbesar $70 \%$ untuk pendapatan antara Rp 600.000 sampai dengan Rp 899.999 sebanyak 6 responden. Pendapatan kepala keluarga antara Rp 900.000 sampai dengan Rp 1.199.999 sebanyak 2 responden, sedangkan untuk persentase terendah berada pada pendapatan kepala keluarga antara Rp 1.200.000 sampai dengan Rp 3.000.000 hanya 1 responden.

Rendahnya pendapatan kepala keluarga ini mendorong istri atau wanita untuk bekerja, guna membantu memenuhi kebutuhan keluarga yang semakin meningkat. Pada saat ini semua harga-harga kebutuhan mengalami kenaikan, baik itu kebutuhan sandang, pangan, papan, pendidikan dan kesehatan, sehingga apabila hanya mengandalkan 
pendapatan suami yang kurang memadai maka kebutuhan rumah tangga tidak akan terpenuhi.

Tetapi ada juga wanita yang pendapatan suaminya besar tetapi ikut bekerja, hal ini disebabkan karena para wanita tersebut ingin menyesuaikan diri dengan cara hidup suami yang cenderung cara hidupnya lebih mewah. Selain itu juga mereka dituntut suami agar ikut bekerja dengan alasan mereka akan mendapatkan kelas sosial yang lebih tinggi di masyarakat apabila istri mereka berpendidikan dan bekerja.

\section{Tanggungan Keluarga}

Hasil penelitian dapat dilihat bahwa rata-rata responden mempunyai tanggapan yang dapat dilihat pada tabel 4.5.

Tabel 4.5 Jumlah Anggota Keluarga yang Masuk dalam Tanggungan Keluarga

\begin{tabular}{|l|c|r|r|}
\hline No. & Jumlah Tanggungan & Jumlah Responden & Persentase (\%) \\
\hline 1. & $3-5$ Orang & 26 & 86,67 \\
\hline 2. & $\geq 6$ Orang & 4 & 13,33 \\
\hline Jumlah & & 30 & 100 \\
\hline
\end{tabular}

Sumber data : Hasil Penelitian, Mei 2010

Dari tabel 4.5 dapat dilihat bahwa responden yang mempunyai tanggungan 3 sampai dengan 5 tanggungan sebanyak 26 responden dengan persentase 86,67\%, lebih atau sama dengan 6 tanggungan sebanyak 4 responden dengan persentase 13,33\% yang merupakan persentase terkecil.

Data di atas dapat dilihat bahwa mayoritas jumlah tanggungan responden yaitu 1 sampai 5 tanggungan, jumlah tanggungan ini membuat para wanita ikut bekerja guna mencukupi kebutuhan keluarga, baik kebutuhan sandang, pangan, papan, pendidikan dan kesehatan, bila hanya mengandalkan pendapatan kepala keluarga untuk mencukupi seluruh kebutuhan, maka kemungkinan besar anak-anak mereka akan putus sekolah dan kesejahteraan keluarga mereka kurang memadai. Jumlah tanggungan para responden ini terdiri dari anak, menantu, orang tua, cucu, dan sanak saudara yang menumpang sementara untuk menyelesaikan studi.

\section{Tingkat Pendidikan Kepala Keluarga}

Dari hasil penelitian diperoleh data mengenai pendidikan kepala keluarga responden, seperti tampak pada tabel 4.6

Tabel 4.6 Tingkat Pendidikan Kepala Keluarga

\begin{tabular}{|l|l|r|r|}
\hline No. & \multicolumn{1}{|c|}{ Tingkat Pendidikan } & Jumlah Responden & \multicolumn{1}{|c|}{ Persentase (\%) } \\
\hline 1. & SD & 12 & 40 \\
\hline 2. & SLTP & 14 & 46,66 \\
\hline 3. & SLTA & 3 & 10 \\
\hline 4. & PT & 1 & 3,33 \\
\hline Jumlah & 30 & 100 \\
\hline
\end{tabular}

Sumber data : Hasil Penelitian, Mei 2010

Tabel 4.6 menunjukkan bahwa tingkat pendidikan kepala keluarga responden dengan persentase tertinggi $46,66 \%$ adalah tamat SLTP. Sedangkan untuk persentase 
terendah 3,33\% adalah tamat perguruan tinggi (PT). Bila dilihat dari hasil penelitian ini, maka tingkat pendidikan kepala keluarga responden kurang baik. Dengan tingkat pendidikan yang rendah biasanya kepala keluarga sulit dalam memperoleh pekerjaan yang layak, biasanya memperoleh pekerjaan yang layak membutuhkan pendidikan yang relatif baik atau sudah lumayan tinggi yaitu rata-rata tamatan SLTA atau lebih di atasnya.

\section{Partisipasi Wanita Bekerja}

Dari hasil penelitian didapatkan bahwa lamanya waktu bekerja yang dicurahkan para responden (wanita pekerja kebersihan) dalam satu hari adalah 8 jam. Lamanya jam kerja para responden ini telah ditentukan oleh Dinas Pertamanan dan Kebersihan Kota Bengkulu. Hasil analisis hubungan antar variabel penelitian dapat dilihat berikut ini:

1. Pendapatan keluarga $\left(\mathrm{X}_{1}\right)$ mempunyai hubungan signifikan dengan partisipasi wanita bekerja.

2. Tanggungan keluarga $\left(\mathrm{X}_{2}\right)$ mempunyai hubungan signifikan dengan partisipasi wanita bekerja.

3. Tingkat pendidikan $\left(\mathrm{X}_{3}\right)$ ada hubungan yang signifikan dengan partisipasi wanita bekerja.

\section{Pembahasan}

Di dalam era sekarang dimana setiap manusia untuk memenuhi kebutuhan ekonomi yang memadai. Tingkat pendapatan kepala keluarga selaku anggota masyarakat mempengaruhi segala aktivitas.Dalam memenuhi kewajiban sebagai kepala keluarga,untuk mencukupi kebutuhan keluarganya sangat diperlukan. Selain untuk memenuhi kebutuhan keluarga, peran partisipasi wanita untuk bekerja sangat diperlukan untuk membantu kepala keluarga yang bependapatan rendah. Kecenderungan bagi kepala keluarga yang berpendapatan tinggi pengeluaran juga tinggi, bagi yang berpendapatan rendah pengeluaran juga rendah. Jadi kecenderungan pengeluaran kebutuhan hidup menyesuaikan dengan pendapatan yang diperolehnya, keseimbangan antara pendapatan dengan pengeluaran. Pendapatan yang dicapai dalam jangka waktu tertentu, senantiasa sama dengan pengeluaran jangka waktu tertentu.

Dalam jumlah anggota keluarga, tanggungan kepala keluarga merupakan salah satu peran paling penting dalam memenuhi kebutuhan hidup. Ukuran jumlah anggota keluarga dimana tangungan keluarga ini ada dua macam yaitu keluarga besar dan keluarga kecil, apalagi ukuran keluarga besar yang taraf ekonominya rendah sangat berperan penting untuk bantuan partisipasi wanita bekerja.

Tingkat pendidikan kepala keluarga yang rendah akan berdampak kepada kemampuan kepala keluarga dalam hal memperoleh pendapatan rumah 1 Biasanya mereka terjun ke sektor informal, dan ini menunjukkan betapa pent pendidikan dalam upaya pemenuhan kebutuhan. Pendidikan seseorang berkoresası positif terhadap pekerjaan dan penghasilan.

\section{KESIMPULAN}

1. Pendapatan Kepala keluarga responden sebagai kebersihan jalan di kota Bengkulu adalah $90 \%$ (27 orang) berpenghasilan antara Rp. 300.000 sd. 900.000,-.

2. Jumlah tanggungan kepala keluarga adalah $86,67 \%$ (26 orang) dengan jumlah tanggungan keluarga antara 3 sd. 5 orang. 
3. Tingkat pendidikan kepala keluarga sebagian besar tamat SMP 46,66 \% (14 orang), $40 \%$ (12 orang) tamat SD dan 3 orang tamat SMA 1 orang tamat Diploma.

4. Tingkat pendidikan responden 22 orang tamat SD (73,33 \%) SMP 6 orang (20 $\%)$ dan 2 orang tamat SMA $(6,66 \%)$

5. Pendapatan keluarga $\left(\mathrm{X}_{1}\right)$ mempunyai hubungan signifikan dengan partisipasi wanita bekerja.

6. Tanggungan keluarga $\left(\mathrm{X}_{2}\right)$ mempunyai hubungan signifikan dengan partisipasi wanita bekerja.

7. Tingkat pendidikan $\left(\mathrm{X}_{3}\right)$ ada hubungan yang signifikan dengan par wanita bekerja.

\section{REFERENCES}

Arikunto Suharsimi. (2006). Prosedur Penelitian Suatu Pendekatan Praktek. Jakarta : Rineka Cipta

Azehari.(2001). Makro Ekonomi.Jakarta : Pustaka Alkautsar

Djarwanto PS dan Pangestu Subagyo.(2000). Statistik Induktif.Yogyakarta : BPFE.

Hasibuan.(2002). Manajemen Sumber Daya Manusia. Edisi Revisi. Jakarta : Bumi Aksara.

Idris, Zahara. (2001). Dasar-Dasar Kepemimpinan.Bandung : Aksara.

Irianto Sulityowati. (2008). Perempuan dan Hukum.Jakarta : Yayasan Obor Indonesia, Anggota IKAPI DKI Jaya.

Kotler, Philip. (2005). Manajemen Pemasaran.Jakarta : Gramedia.

Kusumosuwidho, Sisdjiatmo. (2000). Angkatan Kerja. Dalam Kartomo Wirosuharjo (ed). Dasar-Dasar Demografi (189-221). Jakarta : Lembaga Demografi FE-UI.

Mas’ud, Moh. (2000). Manajemen Personalia.Jakarta : Erlangga.

Masri Singarimbun. (2005). Metode Penelitian Survey.Jakarta : LP3ES Indonesia.

Pratiwi. (2009). Panduan Penulisan Skripsi. Jakarta : Tugu Publisher

Prijono, Tjiptoherijanto. (2002). Prospek Perekonomian Indonesia dalam Rangka Globalisasi.Jakarta : Rineka cipta.

Sadono Sukirno. (2001). Ekonomi Pembangunan.Jakarta : LPFE UI.

Simanjuntak, Payaman, J. (2001). Pengantar Ekonomi Sumber Daya Ekonomi. Jakarta : LPFE UI. 
Smuelson A. (2002). Mikro Ekonomi. Jakarta : Erlangga.

Sondang, Siagian, P. (2004). Teori Pengembangan Organisasi. Jakarta : Bumi Aksara.

Susanti, Hera dkk.(1995). Indikator-Indikator Makro Ekonomi.Jakarta : FE UI bekerjasama dengan Lembaga Penyelidikan Ekonomi dan Masyarakat FE UI.

Yudhohusodo.(2002). Metode Riset Komunikasi Organisasi.Jakarta : Gramedia. 